\title{
Protective Role of Ashwagandha and Selenium against Chlorpyrifos (CPF) Induced Haemato-Biochemical and Hepatic Alterations in Wistar Rats
}

\author{
Vellanki Manvitha ${ }^{1 *}$, A. Gopala Reddy ${ }^{2}$, B. Anil Kumar ${ }^{1}$, \\ M. Jeevanalatha ${ }^{3}$ and G. Priyanka ${ }^{1}$
}

${ }^{1}$ Department of Veterinary Pharmacology and Toxicology, College of Veterinary Science, Rajendranagar, Hyderabad-500030, India

${ }^{2}$ Department of Veterinary Pharmacology and Toxicology, College of Veterinary Science, Korutla, Jagtial-505326, India

${ }^{3}$ Department of Veterinary Pathology, College of Veterinary Science, Mamnoor, Warangal-506166, India

*Corresponding author

\section{A B S T R A C T}

\section{Keywords}

Chlorpyrifos,

Ashwagandha,

Selenium,

Haematology,

Serum

biochemistry,

Oxidative stress

Article Info

Accepted:

10 October 2019

Available Online:

10 November 2019
The present experiment was detailed about the protective effect of Ashwagandha and selenium on chlorpyrifos (CPF) induced changes in haemato-biochemical parameters and liver histology in rats. 42 male albino Wistar rats were procured and divided into 7 groups consisting of 6 in each. Group 1- Normal Control. Group 2 - Chlorpyrifos(@ $2.5 \mathrm{mg} / \mathrm{kg}$ body weight/p.o./day). Group 3 - Ashwagandha (@ $100 \mathrm{mg} / \mathrm{kg}$ body weight/p.o./day). Group 4 - Selenium (@10 $\mu \mathrm{g} / \mathrm{kg}$ body weight/p.o./day). Group 5 - Chlorpyrifos (@ 12.5 $\mathrm{mg} / \mathrm{kg}$ body weight/p.o./day) + Ashwagandha (@100 mg/kg body weight/p.o./day). Group 6 - Chlorpyrifos (@12.5 mg/kg body weight/p.o./day) + Selenium (@10 $\mu \mathrm{g} / \mathrm{kg}$ body weight/p.o./day). Group 7 - Chlorpyrifos(@ $12.5 \mathrm{mg} / \mathrm{kg}$ body weight/p.o./day) + Ashwagandha (@ $100 \mathrm{mg} / \mathrm{kg}$ body weight/p.o./day) + Selenium (@ $10 \mu \mathrm{g} / \mathrm{kg}$ body weight/p.o./day). Group 7 rats revealed a significant $(\mathrm{P}<0.05)$ increase in the mean values of total erythrocyte count (TEC), total leucocyte count (TLC), haemoglobin (Hb) concentration and packed cell volume $(\mathrm{PCV})$ and a significant $(\mathrm{P}<0.05)$ decrease in aspartate amino transferase (AST) and alanine transaminase (ALT) and rejuvenated hepatic parenchyma when compared to group 2 rats. These results suggested that the administration of Ashwagandha and selenium offered remarkable synergistic protective action against CPF induced alterations in haemato-biochemistry and histology.

\section{Introduction}

Organophosphorus pesticides (OPs) are commonly used in agricultural, industrial and domestic settings (Darwiche et al., 2018). Chlorpyrifos $\{\mathrm{O}, \mathrm{O}$-diethyl-o-(3,5,6-trichloro2-pyridyl) phosphorothionate-CPF $\}$ is a broad spectrum organophosphate insecticide, 
commonly used in domestic and industrial applications Globally to kill a wide variety of insects (Olsvik et al., 2015) and is currently in use in more than 100 countries Worldwide (Alavanja et al., 2013).

The widespread use of pesticides in agriculture can lead to soil, water and air contamination resulting in adverse effects on inhabiting non-target organisms (Kartheek and David, 2016). The mechanism of CPF toxicity involves acetylcholinesterase (AChE) inhibition and induction of oxidative stress through production of reactive oxygen species (ROS) which causes damage to macromolecules such as lipids, proteins, and DNA (Ambali et al., 2010). CPF is metabolized in hepatocytes by cytochrome P450 2B6 and converted to CPF oxon (oxygen analogue), which represents the major toxic CPF metabolite (Tanvir et al., 2016). CPF causes multiple organ dysfunctions (liver and heart) due to hypoxia and inadequate tissue perfusion (Kumar et al., 2010).

Ashwagandha is the most familiar ayurvedic medicine and it's root extract has found to alter the oxidative stress markers of the body, reduce the lipid peroxidation (LPO) and increase the superoxide dismutase (SOD) and catalase (CAT) activities, thus carrying free radical scavenging property (Sabiba et al., 2013). Selenium is involved in the synthesis of glutathione peroxidase (reducing peroxides) and thioredoxin reductases (regenerating antioxidant systems) (Barciela et al., 2008).

There is scanty literature available on synergistic action of microelement and herbal combination for their greater antioxidant potentiality.

The aim of this experiment was to investigate the protective effect of ashwagandha and selenium given in combination on haematological, biochemical and histopathological parameters after repeated exposure to CPF in Wistar rats.

\section{Materials and Methods}

In the present study, a total of 42 male albino Wistar rats weighing 150-180 grams were procured from Jeeva Life Sciences Pvt. Limited, Hyderabad. The rats were housed in solid bottom polypropylene cages at the lab animal house, Department of Veterinary Pharmacology and Toxicology, College of Veterinary Science, Hyderabad and were maintained at ambient temperature $\left(20-22^{\circ} \mathrm{C}\right)$ throughout the course of experiment. Sterile husk was used as standard bedding material. All the rats were provided with standard pellet diet obtained from National Institute of Nutrition (NIN), Hyderabad and ad libitum water throughout the experimental period. Rats were randomly divided into 7 groups consisting of 6 in each group. Group 1 served as normal control whereas group 2 served as CPF toxic control (@ $12.5 \quad \mathrm{mg} / \mathrm{kg}$ b.w./p.o./day). Groups 3 and 4 were administered with Ashwagandha @ 100 mg/kg body weight/p.o./day and Selenium @ $10 \mu \mathrm{g} / \mathrm{kg}$ body weight/p.o./day, respectively and served as non-toxic controls. Group 5 was administered with CPF @ $12.5 \mathrm{mg} / \mathrm{kg}$ body weight/p.o./day + Ashwagandha @ 100 mg/kg body weight/p.o./day. Group 6 was administered with CPF @ $12.5 \mathrm{mg} / \mathrm{kg}$ body weight/p.o./day + Selenium @ 10 $\mu \mathrm{g} / \mathrm{kg}$ body weight/p.o./day. Group 7 was administered with CPF @ $12.5 \mathrm{mg} / \mathrm{kg}$ body weight/p.o./day + Ashwagandha @ $100 \mathrm{mg} / \mathrm{kg}$ body weight/p.o./day + Selenium @ 10 $\mu \mathrm{g} / \mathrm{kg}$ body weight/p.o./day. The experiment was carried out according to the guidelines and prior approval of Institutional Animals Ethics Committee (IAEC-No. III/201905/IAEC/C.V.Sc., Hyd, Dated 17/04/2019).

\section{Drugs and chemicals}

Chlorpyrifos (Chlorpyrifos 20\% EC) was 
procured from Insecticides India Ltd. Root powder of Ashwagandha was obtained from KSM-66 Ashwagandha. Selenium as sodium selenite was procured from Sisco Research Laboratories Pvt. Ltd., Taloja, Maharashtra, India. Stains for the histopathological study of liver were obtained from Qualigens Pvt. Ltd., Mumbai.

\section{Haematology and biochemistry}

Prior to blood collection, the selected experimental rats were put to fast for 12 hours. Blood collection was carried out at fortnight intervals for haematological and serobiochemical analysis after initiation of the drug administration till the end of experiment. Approximately, 2-3ml of blood was collected through retro-orbital plexus with the help of capillary tube into an anticoagulant coated vacutainer $\left\{\mathrm{K}_{3}\right.$-EDTA tube, $13 \mathrm{~mm} \times 75 \mathrm{~mm}$, 4mL (Rapid Diagnostics Pvt. Ltd., Delhi)\} for analysis of all haematological parameters and into serum vacutainers to analyse biochemical parameters. The whole blood was used for estimation of Total Erythrocyte Count (TEC), Total Leucocyte Count (TLC), Haemoglobin $(\mathrm{Hb})$ concentration and Packed Cell Volume (PCV) by using automatic whole blood analyser (Huma count, med source ozone biomedical Pvt. Ltd., Faridabad, Haryana). Blood collected in serum vacutainers was centrifuged at $3000 \mathrm{RPM}$ for $15 \mathrm{~min}$, and serum was separated and stored at $-80{ }^{\circ} \mathrm{C}$ till analysis. Kits for AST and ALT estimation were procured from ERBA diagnostics Ltd, Surat, India.

\section{Histopathology}

On the $28^{\text {th }}$ day, after blood collection, rats were euthanized by carbon dioxide exposure and tissue pieces of liver were collected from the rats and fixed in 10\% neutral buffered formalin (NBF) for histopathology. The small representative pieces of fixed tissues were cut and subjected to overnight washing under running tap water. The tissues were then dehydrated in ascending grades of alcohol, cleared in xylol and embedded in paraffin at $55-56^{\circ} \mathrm{C}$. The paraffin blocks were cut into thin sections of 5 micron thickness by microtome. The cut sections were lifted on grease free glass slides precoated with Mayer's egg albumin and were kept in incubator overnight at $37^{\circ} \mathrm{C}$ for drying. The slides were stained with routine Haematoxylin and Eosin (H and E) stain (Clayden, 1962; Culling, 1974) and the stained sections were mounted with DPX mountant and kept ready for microscopic examination (Fig. 1-7).

Data obtained (haematological and biochemical parameters) was subjected to statistical analysis by applying one-way ANOVA and using statistical package for social sciences (SPSS) version 25.0. Differences between the means were tested by using Duncan's multiple comparison tests and significance level was set at $\mathrm{P}<0.05$ (Snedecor and Cochran, 1994).

\section{Results and Discussion}

\section{Haematology}

The mean values of TEC (millions $/ \mu \mathrm{L}$ ) in different groups $(1,2,3,4,5,6$ and 7) were ranged from $5.82 \pm 0.02$ to $9.28 \pm 0.07$ on $14^{\text {th }}$ day and $5.08 \pm 0.05$ to $9.30 \pm 0.02$ on $28^{\text {th }}$ day of experiment. Significantly $(\mathrm{P}<0.05)$ decreased values were observed in group 2 rats when compared to all other groups on $14^{\text {th }}$ and $28^{\text {th }}$ day of experiment. The treatment group 7 showed significant $(\mathrm{p}<0.05)$ improvement in the TEC values when compared to the treatment groups 5 and 6 (Table 1).

The mean values of TLC (thousands/ $\mu \mathrm{L}$ ) in different groups $(1,2,3,4,5,6$ and 7) were ranged from $11.50 \pm 0.12$ to $15.57 \pm 0.08$ on 
$14^{\text {th }}$ day and $10.51 \pm 0.13$ to $15.58 \pm 0.05$ on $28^{\text {th }}$ day of experiment. Group 2 rats showed a significant $(\mathrm{P}<0.05)$ decrease in the TLC values when compared to all other group rats on $14^{\text {th }}$ and $28^{\text {th }}$ day of the experiment. The treatment group 7 showed significant $(p<0.05)$ improvement in the TLC when compared to treatment groups 5 and 6 (Table 1).

The concentration of $\mathrm{Hb}(\mathrm{g} / \mathrm{dl})$ in different groups (1, 2, 3, 4, 5, 6 and 7) ranged from $11.57 \pm 0.04$ to $14.29 \pm 0.30$ on $14^{\text {th }}$ day and $10.17 \pm 0.05$ to $14.40 \pm 0.32$ on $28^{\text {th }}$ day of experiment. The concentration of $\mathrm{Hb}(\mathrm{g} / \mathrm{dl})$ in group 2 was significantly $(\mathrm{p}<0.05)$ lower when compared to all other groups on $14^{\text {th }}$ and $28^{\text {th }}$ day. The treatment group 7 showed significant $(\mathrm{p}<0.05)$ improvement in the $\mathrm{Hb}$ when compared to groups 5 and 6 on $14^{\text {th }}$ and $28^{\text {th }}$ day and the values were insignificant between groups ( 1 and 7 ) of group 7 was comparable on $28^{\text {th }}$ day (Table 2 ).

The PCV (\%) mean values in group 2 were significantly $(\mathrm{p}<0.05)$ lower compared to the control and treatment groups on $14^{\text {th }}$ and $28^{\text {th }}$ day. The values of groups 5, 6 and 7 were comparable without any significant difference and were comparable to group 1 (Table 2).

The activity of AST (IU/L) in group 2 $(86.23 \pm 1.85$ and $96.06 \pm 1.06)$ was significantly $(\mathrm{p}<0.05)$ higher when compared to group 1 $(62.76 \pm 2.30$ and $63.11 \pm 2.43)$, while group 5 $(78.84 \pm 1.88$ and $73.49 \pm 1.09)$, group 6 $(79.34 \pm 1.85$ and $73.99 \pm 1.39)$ and group 7 $(75.43 \pm 1.00$ and $69.55 \pm 0.83)$ showed significantly $(p<0.05)$ lower values in comparison to group 2 on $14^{\text {th }}$ and $28^{\text {th }}$ day of experiment. The values of groups 5, 6 and 7 were comparable without any significant difference (Table 3).

The activity of ALT (IU/L) in group 2 (55.95 \pm 1.14 and 67.09 \pm 1.07$)$ was significantly $(\mathrm{p}<0.05)$ higher compared to group 1
$(34.03 \pm 1.43$ and $33.83 \pm 1.44)$ whereas treatment group $5 \quad(49.04 \pm 1.01$ and $43.91 \pm 0.95)$, group $6 \quad(48.54 \pm 1.09$ and $43.71 \pm 0.96)$ and group $7(46.94 \pm 0.83$ and $41.67 \pm 0.77)$ exhibited significantly $(\mathrm{p}<0.05)$ lower values in comparison to group 2 on $14^{\text {th }}$ and $28^{\text {th }}$ day of experiment. The mean values of groups 5, 6 and 7 were comparable without any significant difference (Table 3 ).

The sections of the liver from group 2 showed thickened and dilated portal vein (PV) with congestion, haemorrhages in sinusoids, mild proliferation of Kupffer cells, narrowed sinusoids and degenerative changes of hepatocytes (Figure 2), whereas the treated groups showed dilation and mild congestion of central vein and focal areas of reduced sinusoidal space (Figure 5) in group 5, mild proliferation of Kupffer cells and mild dilatation of sinusoids (Figure 6) in group 6 and normal radiating appearance of hepatic cords with mild dilation of central vein $(\mathrm{CV})$ (Figure 7) in group 7.

A significant change in haematological parameters in the present study may be due to dysfunction of haemopoietic system. A decreased TEC and $\mathrm{Hb}$ concentration might be attributed to the increased lipoperoxidation in the CPF group, which was reflected by significant increase in malondialdehyde (MDA) levels leading to haemolytic anaemia.

These findings are in agreement with the previous report of Mossa (2004). Decrease in the PCV may be due to the increased rate of breakdown of RBCs. Decrease in TLC may be due to free radical-induced oxidative damage and these observations are in accordance with Albasher et al., (2019).

The increase in the activity of AST and ALT may be due to liver dysfunction and alteration in the permeability of liver membrane leading to their leakage into blood stream. 
Table.1 Total erythrocyte count (millions/ $\mu \mathrm{L}$ ) and total leucocyte count (thousands $/ \mu \mathrm{L}$ ) in different groups

\begin{tabular}{|c|c|c|c|c|}
\hline \multirow{2}{*}{ GROUP } & \multicolumn{2}{|c|}{ TEC(Millions/ $\boldsymbol{\mu L}$ ) } & \multicolumn{2}{c|}{ TLC(Thousands/ $\boldsymbol{\mu L}$ ) } \\
\cline { 2 - 5 } & DAY 14 & DAY 28 & DAY 14 & DAY 28 \\
\hline G1 & $9.15 \pm 0.06^{\mathrm{d}}$ & $9.12 \pm 0.04^{\mathrm{d}}$ & $15.55 \pm 0.12^{\mathrm{d}}$ & $15.48 \pm 0.10^{\mathrm{d}}$ \\
\hline G2 & $5.82 \pm 0.02^{\mathrm{a}}$ & $5.08 \pm 0.05^{\mathrm{a}}$ & $11.50 \pm 0.12^{\mathrm{a}}$ & $10.51 \pm 0.13^{\mathrm{a}}$ \\
\hline G3 & $9.28 \pm 0.07^{\mathrm{d}}$ & $9.30 \pm 0.02^{\mathrm{d}}$ & $15.55 \pm 0.11^{\mathrm{d}}$ & $15.56 \pm 0.11^{\mathrm{d}}$ \\
\hline G4 & $9.22 \pm 0.05^{\mathrm{d}}$ & $9.25 \pm 0.08^{\mathrm{d}}$ & $15.57 \pm 0.08^{\mathrm{d}}$ & $15.58 \pm 0.05^{\mathrm{d}}$ \\
\hline G5 & $6.78 \pm 0.18^{\mathrm{b}}$ & $6.84 \pm 0.10^{\mathrm{b}}$ & $12.57 \pm 0.06^{\mathrm{b}}$ & $13.02 \pm 0.12^{\mathrm{b}}$ \\
\hline G6 & $6.51 \pm 0.12^{\mathrm{b}}$ & $6.74 \pm 0.18^{\mathrm{b}}$ & $12.59 \pm 0.07^{\mathrm{b}}$ & $13.09 \pm 0.16^{\mathrm{b}}$ \\
\hline G7 & $7.16 \pm 0.09^{\mathrm{c}}$ & $7.77 \pm 0.14^{\mathrm{c}}$ & $13.40 \pm 0.08^{\mathrm{c}}$ & $13.96 \pm 0.11^{\mathrm{c}}$ \\
\hline
\end{tabular}

Values are Mean \pm SE $(n=6)$; One-way ANOVA

Means with different superscripts in a column differ significantly at $\mathrm{P}<0.05(*)$.

Table.2 Haemoglobin concentration ( $\mathrm{g} \%)$ and packed cell volume (\%) in different groups

\begin{tabular}{|c|c|c|c|c|}
\hline \multirow{2}{*}{ GROUP } & \multicolumn{2}{|c|}{ Hb (g/dl) } & & \multicolumn{2}{c|}{ PCV (\%) } \\
\cline { 2 - 5 } & DAY 14 $^{*}$ & DAY 28 & DAY 14 & DAY 28 \\
\hline G1 & $14.05 \pm 0.09^{\mathrm{d}}$ & $14.15 \pm 0.10^{\mathrm{c}}$ & $41.21 \pm 1.14^{\mathrm{c}}$ & $41.11 \pm 0.82^{\mathrm{bc}}$ \\
\hline G2 & $11.57 \pm 0.04^{\mathrm{a}}$ & $10.17 \pm 0.05^{\mathrm{a}}$ & $34.09 \pm 0.87^{\mathrm{a}}$ & $33.46 \pm 1.03^{\mathrm{a}}$ \\
\hline G3 & $14.29 \pm 0.30^{\mathrm{d}}$ & $14.40 \pm 0.32^{\mathrm{c}}$ & $41.69 \pm 1.04^{\mathrm{c}}$ & $42.06 \pm 1.03^{\mathrm{c}}$ \\
\hline G4 & $14.14 \pm 0.07^{\mathrm{d}}$ & $14.27 \pm 0.39^{\mathrm{c}}$ & $41.78 \pm 0.97^{\mathrm{c}}$ & $41.98 \pm 1.32^{\mathrm{c}}$ \\
\hline G5 & $12.23 \pm 0.11^{\mathrm{b}}$ & $12.84 \pm 0.13^{\mathrm{b}}$ & $37.57 \pm 1.21^{\mathrm{b}}$ & $37.72 \pm 1.48^{\mathrm{b}}$ \\
\hline G6 & $12.13 \pm 0.12^{\mathrm{b}}$ & $12.52 \pm 0.26^{\mathrm{b}}$ & $37.87 \pm 0.93^{\mathrm{b}}$ & $37.89 \pm 1.49^{\mathrm{b}}$ \\
\hline G7 & $13.29 \pm 0.19^{\mathrm{c}}$ & $14.01 \pm 0.32^{\mathrm{c}}$ & $38.87 \pm 0.89^{\mathrm{bc}}$ & $39.20 \pm 0.95^{\mathrm{bc}}$ \\
\hline
\end{tabular}

Values are Mean $\pm \mathrm{SE}(\mathrm{n}=6)$; One-way ANOVA

Means with different superscripts in a column differ significantly at $\mathrm{P}<0.05(*)$.

Table.3 Aspartate aminotranferase (IU/L) and alanine transaminase (IU/L) in different groups

\begin{tabular}{|c|c|c|c|c|}
\hline \multirow{2}{*}{ GROUP } & \multicolumn{2}{|c|}{ AST (IU/L) } & \multicolumn{2}{c|}{ ALT (IU/L) } \\
\cline { 2 - 5 } & DAY 14 & DAY 28 & DAY 14 & DAY 28 \\
\hline G1 & $62.76 \pm 2.30^{\mathrm{a}}$ & $63.11 \pm 2.43^{\mathrm{a}}$ & $34.03 \pm 1.43^{\mathrm{a}}$ & $33.83 \pm 1.44^{\mathrm{a}}$ \\
\hline G2 & $86.23 \pm 1.85^{\mathrm{c}}$ & $96.06 \pm 1.06^{\mathrm{c}}$ & $55.95 \pm 1.14^{\mathrm{c}}$ & $67.09 \pm 1.07^{\mathrm{c}}$ \\
\hline G3 & $62.26 \pm 2.32^{\mathrm{a}}$ & $61.93 \pm 2.35^{\mathrm{a}}$ & $33.73 \pm 1.42^{\mathrm{a}}$ & $33.49 \pm 1.48^{\mathrm{a}}$ \\
\hline G4 & $62.28 \pm 2.40^{\mathrm{a}}$ & $61.95 \pm 2.27^{\mathrm{a}}$ & $33.57 \pm 1.28^{\mathrm{a}}$ & $33.35 \pm 1.52^{\mathrm{a}}$ \\
\hline G5 & $78.84 \pm 1.88^{\mathrm{b}}$ & $73.49 \pm 1.09^{\mathrm{b}}$ & $49.04 \pm 1.01^{\mathrm{b}}$ & $43.91 \pm 0.95^{\mathrm{b}}$ \\
\hline G6 & $79.34 \pm 1.85^{\mathrm{b}}$ & $73.99 \pm 1.39^{\mathrm{b}}$ & $48.54 \pm 1.09^{\mathrm{b}}$ & $43.71 \pm 0.96^{\mathrm{b}}$ \\
\hline G7 & $75.43 \pm 1.00^{\mathrm{b}}$ & $69.55 \pm 0.83^{\mathrm{b}}$ & $46.94 \pm 0.83^{\mathrm{b}}$ & $41.67 \pm 0.77^{\mathrm{b}}$ \\
\hline
\end{tabular}

Values are Mean \pm SE ( $n=6)$; One-way ANOVA

Means with different superscripts in a column differ significantly at $\mathrm{P}<0.05$ (*). 
Fig.1 Microphotograph of liver showing normal architecture of lobule with radiating appearance of hepatic cords (Group 1): H\&E $\mathrm{X} 100 \mu \mathrm{m}$

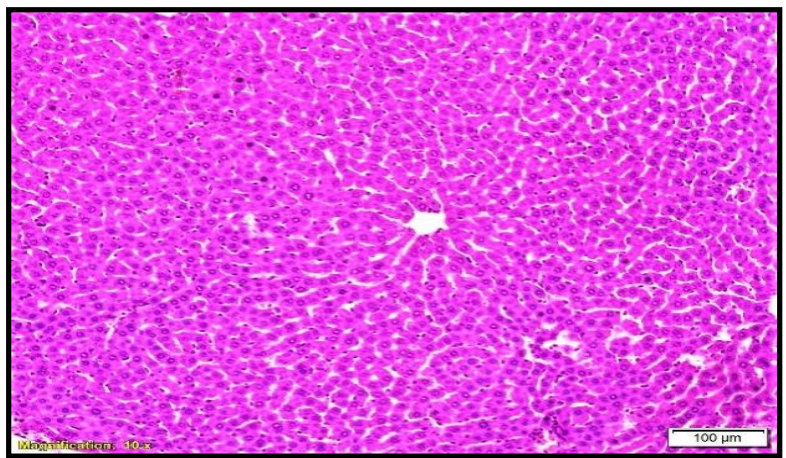

Fig.3 Microphotograph of liver showing normal architecture of liver lobules with radiating appearance of hepatic cords.

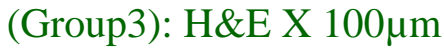

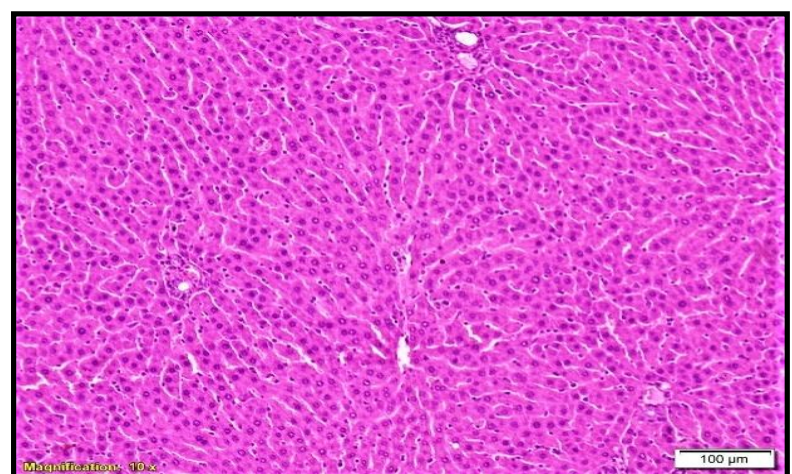

Fig.5 Microphotograph of liver showing dilation and mild congestion of central vein and focal areas with reduced sinusoidal

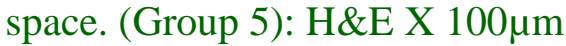

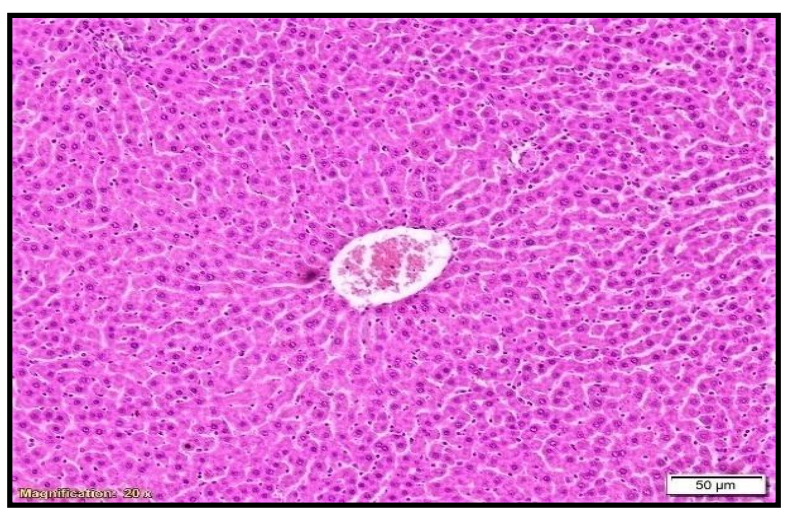

Fig.2 Microphotograph of liver showing thickened and dilated portal vein with congestion, haemorrhages in sinusoidal spaces, mild proliferation of Kupffer cells, reduced sinusoidal space with degenerative changes of hepatocytes and moderate distribution of dark round cells (Group 2):

$\mathrm{H} \& \mathrm{E}$ X $200 \mu \mathrm{m}$

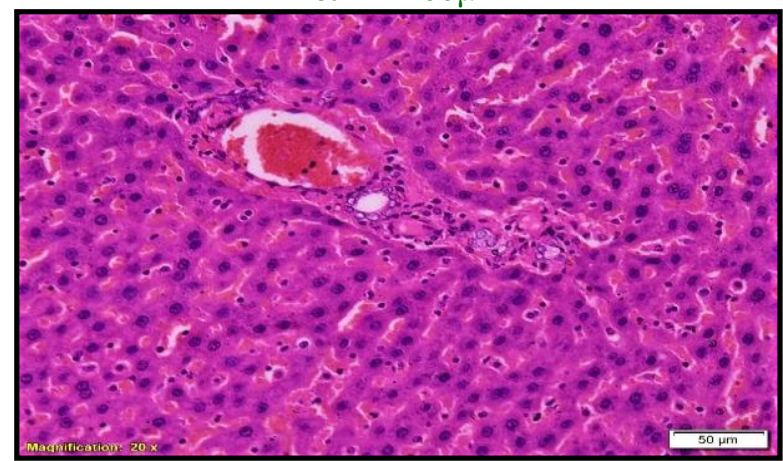

Fig.4 Microphotograph of liver showing normal radiating appearance of hepatic cords within liver lobule. (Group 4): H\&E X 200um

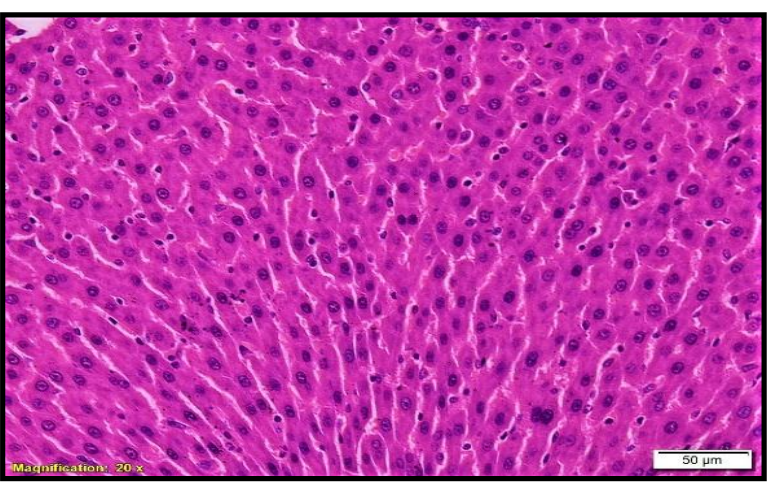

Fig.6 Microphotograph of liver showing mild congestion of central vein, mild proliferation of Kupffer cells and mild dilatation of sinusoidal spaces (Group 6): H\&E X 200um

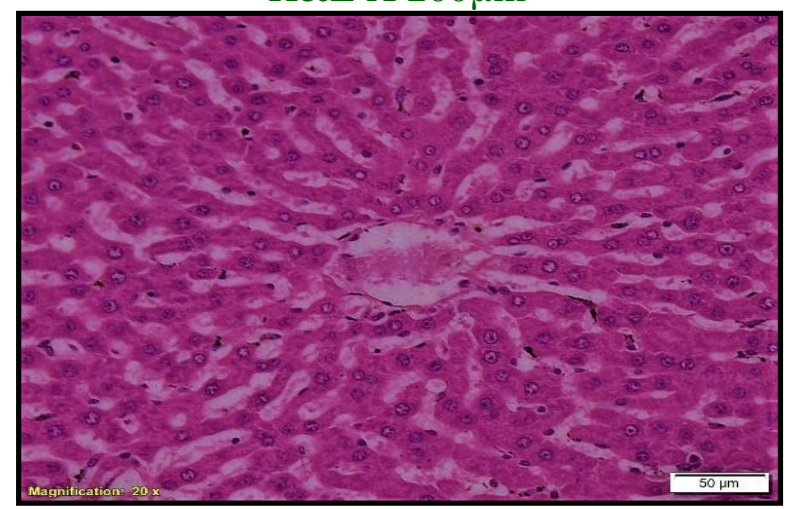


Fig.7 Microphotograph of liver showing normal radiating appearance of hepatic cords with

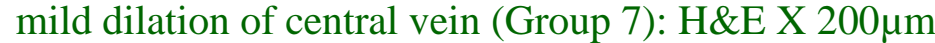

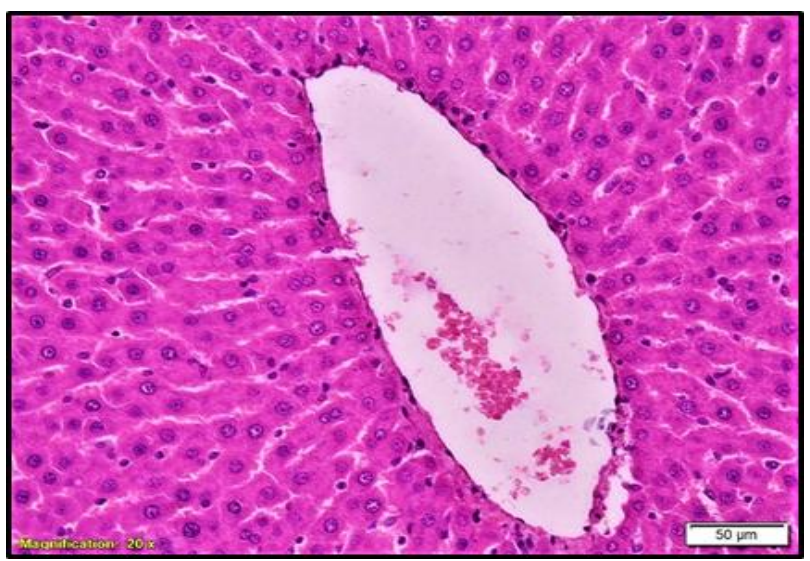

These observations are similar to the earlier studies of Khan et al., (2009); Krishna and Ramachandran (2009) and Wang et al., (2009). These results are further substantiated by marked histopathological changes in the liver like portal vein congestion and haemorrhages in sinusoidal spaces.

In the present study, protective effect of ashwagandha could be due to its antioxidant defensive mechanism by scavenging free radicals and these results are in harmony with the earlier studies of Harikrishnan et al., (2008) and Sujatha et al., (2010). Selenium alleviated $\mathrm{CPF}$ induced liver damage in the present study, which could be due to its antioxidant properties as it is a constituent of selenoenzyme-GSH-Pxand these findings are in agreement with the previous studies of Kaushal et al., (2011) and Abdel-Rahman et al., (2017).

In group 7, a significant increase in the mean values of TEC, TLC, $\mathrm{Hb}$ and PCV, significant decrease in the values of AST and ALT and restoration of architectural details in liver tissues were observed when compared to group 2 which might be due to combined antioxidant defence mechanism of ashwagandha and selenium against chlorpyrifos induced oxidative damage of blood cells and liver tissues.
In conclusion, the present study clearly demonstrated that both Ashwagandha and selenium synergistically attenuate CPF induced haematological, biochemical and histopathological alterations in liver, possibly via antioxidant defence mechanism.

\section{Acknowledgements}

The authors are thankful to P V Narsimha Rao Telangana Veterinary University for providing support and necessary facilities to carry out the research work.

\section{References}

Abdel-Rahman, G. H., El-Metwally, A. E., ElHallawany, H. A., and Ali, A. H. (2017). Protecting role of Selenium on the cytotoxic effect of Profenofos on rabbit fertility. Alexandria Journal for Veterinary Sciences. 54 (1): 79-96.

Alavanja, M. C., Ross, M. K. and Bonner, M. R. (2013). Increased cancer burden among pesticide applicators and others due to pesticide exposure. $C A$ : $A$ Cancer Journal for Clinicians. 63(2): 120-142.

Albasher, G., Almeer, R., Al-Otibi, F. O., AlKubaisi, N. and Mahmoud, A. M. (2019). Ameliorative effect of beta vulgaris root extract on chlorpyrifos- 
induced oxidative stress, inflammation and liver injury in rats. Biomolecules. 9 (7): 261.

Ambali, S. F., Abubakar, A. T., Shittu, M., Yaqub, L. S., Kobo, P. I. andGiwa, A. (2010). Zinc ameliorates chlorpyrifosinduced increased erythrocyte fragility and lipoperoxidative changes in Wistar rats. New York Science Journal. 3: 117-122.

Barciela, J., Herrero, C., García-Martín, S. and Peña, R. M. (2008). A brief study of the role of selenium as antioxidant. EJEAFChe, 7: 3151-3155.

Clayden, E.C.(1962). Practical section cutting and staining, 4th edition, Pp. 137-139.

Culling, C.F.A.(1974). Hand book of histopathological technique, 421.

Darwiche, W., Gay-Quéheillard, J., Delanaud, S., El Sabbouri, H. E. K., Khachfe, H., Joumaa, W. and Ramadan, W. (2018). Impact of chronic exposure to the pesticide chlorpyrifos on respiratory parameters and sleep apnea in juvenile and adult rats. PloS one. 13(1): e0191237.

Harikrishnan, B., Subramanian, P. andSubash, S. (2008). Effect of Withania somnifera root powder on the levels of circulatory lipid peroxidation and liver marker enzymes in chronic hyperammonemia. Journal of Chemistry. 5 (4): 872-877.

Kartheek, R. M. and David, M. (2016). Fipronil induced modulations in biochemical and histopathological aspects of male Wistar albino rats: A subchronic study. Journal of Environment and Biosciences, (5), 2632.

Kaushal, N., Hegde, S., Lumadue, J., Paulson, R. F. and Prabhu, K. S. (2011). The regulation of erythropoiesis by selenium in mice. Antioxidants and Redox Signaling. 14 (8): 1403-1412.

Khan, A., Faridi, H.A.M., Ali, M., Khan,
M.Z., Siddique, M., Hussain, M. and Ahmad, M. (2009): Effects of cypermethrin on some clinico-hematobiochemical and pathological parameters in male dwarf goats (Capra hircus). Experimental Toxicology and Pathology. 61: 151-160.

Krishna, H. and Ramachandran, A. V. (2009). Biochemical alterations induced by the acute exposure to combination of chlorpyrifos and lead in Wistar rats. Biology and Medicine. 1 (2): 1-6.

Kumar, S. V., Fareedullah, M. D., Sudhakar, Y., Venkateswarlu, B. and Kumar, E. A. (2010). Current review on organophosphorus poisoning. Archives of Applied Science and Research. 2(4): 199-215.

Mossa, A. H. (2004). Genotoxicity of pesticides, Doctoral dissertation, Pesticide chemistry and faculty of Agriculrure Damanhour Alexandria University.

Olsvik, P. A., Berntssen, M. H. andSøfteland, L. (2015). Modifying effects of vitamin $\mathrm{E}$ on chlorpyrifos toxicity in Atlantic salmon. PloS one. 10(3): e0119250.

Sabiba, E. P., Rasool, M., Vedi, M., Navaneethan, D., Ravichander, M., Parthasarathy, P. and Thella, S. R. (2013). Hepatoprotective and antioxidant potential of Withania somnifera against paracetamol-induced liver damage in rats. International Journal of Pharmacy and Pharmaceutical Sciences. 5(2): 648651.

Snedecor, G. W. and Cochran, W. G.(1994). Statistical methods, $8{ }^{\text {th }}$ Edn., Ames: Iowa State Univ. Press Iowa.

Sujatha, V., Korde, P. J., Rastogi, S. K., Madan, A. K., Maini, S. and Ravikanth, K. (2010). Amelioration of oxidative stress in broilers during summer. Biotechnology in Animal 
Husbandry. 26 (5-6): 361-381.

Tanvir, E.M.; Afroz, R.; Chowdhury, M.; Gan,

S.H.; Karim, N.; Islam, M.N. and Khalil, M.I. (2016). A model of chlorpyrifos distribution and its biochemical effects on the liver and kidneys of rats. Human and Experimental Toxicology: 35, 991-
1004.

Wang, H.P., Liang, Y.J., Long, D. X., Chen, J. X., Hou, W. Y. and Wu, Y. J. (2009): Metabolic Profiles of Serum from Rats after Subchronic Exposure to Chlorpyrifos and Carbaryl. Chemical Research Toxicology. 22(6): 10261033.

\section{How to cite this article:}

Vellanki Manvitha, A. Gopala Reddy, B. Anil Kumar, M. Jeevanalatha and Priyanka, G. 2019. Protective Role of Ashwagandha and Selenium against Chlorpyrifos (CPF) Induced HaematoBiochemical and Hepatic Alterations in Wistar Rats. Int.J.Curr.Microbiol.App.Sci. 8(11): 941949. doi: https://doi.org/10.20546/ijcmas.2019.811.110 